\title{
Kepemimpinan Kepala Sekolah dalam Pengelolaan Ekstrakurikuler
}

\author{
Teguh Yunianto*, Ahmad Surohman, Niswatun Hasanah \\ FITK Universitas Islam Negeri Sunan Kalijaga Yogyakarta \\ Jl. Laksda Adisucipto, Papringan, Caturtunggal, Kec. Depok, Kabupaten Sleman, Daerah Istimewa Yogyakarta \\ *Corresponding Author.e-mail: teguhyunianto96@gmail.com
}

\begin{abstract}
Abstrak
Kepemimpinan merupakan faktor yang paling penting terhadap ketercapaian tujuan suatu organisasi baik organisasi pendidikan ataupun organisasi di luar pendidikan. Penelitian ini bertujuan untuk mengetahui peran kepemimpinan kepala sekolah dalam pengelolaan ekstrakurikuler. Metode penelitian yang digunakan adalah metode kualitatif dengan pendekatan deskripsi. Teknik pengumpulan data yang digunakan yaitu wawancara dan dokumentasi. Jenis analisis data menggunakan model Miles dan Huberman yaitu pengumpulan data, reduksi data, display data, verifikasi dan penegasan kesimpulan. Lokasi penelitian adalah di MI Ma'arif Bego Yogyakarta. Subjek penelitiannya yaitu kepala sekolah, wakil kepala sekolah, dua orang pelatih ekstrakurikuler, dan tiga orang siswa/siswi. Hasil penelitian menjelaskan bahwa kepemimpinan kepala sekolah dalam pengelolaan ekstrakurikuler sudah sangat baik. Kepala sekolah memiliki kompetensi yang baik dalam melakukan tugas-tugasnya. Kegiatan ekstrakurikuler meliputi silat, tahfiz, pramuka, sepak bola, badminton, catur, renang, dan hadro. Pramuka, silat, dan tahfiz merupakan kegiatan ekstrakulikuler yang wajib diikuti oleh siswa. Terdapat kendala dalam pengelolaan ekstrakurikuler seperti ketersediaan guru, fasilitas, dan kendala musim.
\end{abstract}

Kata kunci: kepemimpinan, pengelolaan, ekstrakurikuler

\section{The Role of Principal's Leadership in Extracurricular Management}

\begin{abstract}
Leadership is the most important factor for the achievement of the goals of an organization, both educational organizations and non-educational organizations. This study aims to determine the role of the principal's leadership in extracurricular management. This research method used is a qualitative method with a descriptive approach. The data collection techniques used were interviews and documentation. Types of data analysis using the Miles and Huberman model, namely data collection data reduction, data display, verification, and confirmation of conclusions. The research location in this study is located at MI Maarif Bego Yogyakarta. With the research subjects, namely the principal, vice-principal, two extracurricular trainers, and three students. The results of the study explained that in MI Maarif Bego the principal's leadership in extracurricular management was already very good. The principal has good competence in carrying out his duties. The extracurricular activities at MI Maarif Bego include Silat, tahfidz, scout, soccer, badminton, chess, swimming, and hadroh activities. The extracurricular activities that are required of students are Scouts, silat, and tahfidz. But in management, still has constraints such as the availability of teachers, facilities and season constraints.
\end{abstract}

Keywords: leadership, management, extracurricular.

How to Cite: Yunianto, T., Surohman, A., \& Hasanah, N. (2021). Peran kepemimpinan kepala sekolah dalam pengelolaan ekstrakurikuler. Jurnal Penelitian Ilmu Pendidikan, 14(1), 22-30. doi:https://doi.org/10.21831/jpipfip.v14i1.32233.

Received 06-06-2020; Received in revised from 14-01-2021; Accepted 01-02-2021 
Jurnal Penelitian Ilmu Pendidikan, 14 (1), 2021 - 23

Yunianto, Surohman, \& Hasanah

\section{PENDAHULUAN}

Pendidikan merupakan suatu usaha untuk memberikan pengaruh kepada peserta didik supaya dapat berinteraksi dengan lingkungan, sehingga akan muncul perubahan pada peserta didik sebagai pengaplikasian diri terhadap kehidupan bermasyarakat (Umar, 2001). Hal ini selaras dengan undangundang no. 20 tahun 2003 tentang sistem pendidikan nasional yang menjelaskan mengenai pendidikan adalah usaha sadar dan terencana dalam menciptakan situasi belajar terhadap proses pembelajaran supaya peserta didik dapat mengembangkan potensi diri dan mempunyai kekuatan spritual keagamaan, pengontrolan diri, kecerdasan, akhlak mulia serta keterampilan lain sebagai potensi yang dapat mendorong kemajuan diri, masyarakat, bangsa, dan negara. Dalam mendapatkan tujuan pendidikan nasional diperlukan sumbangsih dari berbagai pihak untuk mendukung pencapaian tujuan pendidikan tersebut. Oleh sebab itu, pendidikan harus mendapatkan perhatian khusus dan diprioritaskan oleh pemerintah atau seluruh komponen yang terlibat dalam menjalankan sistem pendidikan. Komponen tersebut berupa kepala sekolah.

Sedarwan (Makmur, 2012) berpendapat bahwa kepala sekolah merupakan pemimpin sekaligus pengajar yang bertanggung jawab terhadap pengelolaan pendidikan. Selain itu juga, kepala sekolah dapat dikatakan sebagai komponen pendidikan yang berperan penting terhadap peningkatan kualitas pendidikan (Kodiran, 2017), karena berhasilnya suatu pendidikan dipengaruhi kepemimpinan kepala sekolah dalam meningkatkan kualitas pendidikan (Kasidah, 2017). Hal ini didukung oleh pernyataan Muniarti yang mengatakan bahwa kepemimpinan sebagai tolak ukur yang bersifat kursial terhadap tugas dan tanggung jawab yang erat kaitannya dengan wewenang kepala sekolah. Kualitas dan kuantitas pendidikan dapat dipengaruhi oleh mutu kepemimpinan seorang pemimpin (Kasidah, 2017).

Kepeminpinan merupakan faktor yang paling penting terhadap ketercapaian tujuan suatu organisasi baik organisasi pendidikan ataupun organisasai di luar pendidikan. Kegiatan ekstrakurikuler dapat berhasil jika kegiatan tersebut mampu mengembangkan bakat dan minat yang dimiliki siswa secara baik dan berkelanjutan. Kegiatan ekstrakurikuler ini berguna untuk memperluas wawasan siswa yang pada akhirnya akan mendukung kegiatan intrakurikuler yang dilakukan selama jam sekolah. Oleh karenanya, pihak sekolah seharusnya mendukung dan mengadakan kegiatan ekstrakurikuler tersebut. Kegiatan ektrakurikuler tidak akan berhasil jika tidak dikelola dengan baik oleh komponen yang terlibat dalam pengelolaan pendidikan. Oleh karenanya, pendidikan penting dilakukan di setiap kegiatan (Andriani et al., 2019; Hartinah et al., 2019; Huda et al., 2020). Apabila kegiatan ektrakurikuler dikelola secara efektif maka akan berpengaruh terhadap kemajuan kegiatan intrakurikuler bahkan akan mendukung perubahan sekolah menjadi lebih baik. Pengelolaan dan manajemen yang baik untuk kemajuan kegiatan dalam dunia pendidikan sangat berpengaruh pada perkembangan pendidikan. Permasalahan yang muncul juga dapat disebabkan kurang maksimalnya perancangan dan manajemen kegiatan tersebut sebelumnya.

Penelitian ini ditetapkan di MI Ma'arif bego karena MI tersebut salah satu sekolah yang merencanakan dan melaksanakan kegiatan ektrakurikuler. Kegiatan-kegiatan tersebut di antaranya silat, tahfidz, pramuka, sepak bola, badminton, catur, renang, dan hadroh. Namun, berdasarkan dari hasil observasi awal dan wawancara dengan salah satu siswa di sekolah tersebut yang berinisial MS, yang mengatakan bahwa "tidak semua program ektrakurikuer berjalan dengan lancar, ada kegiatan yang terealisasi dan ada juga yang tidak terealisasi, seperti di antaranya kegiatan renang, badminton, serta hadroh dan kegiatan-kegiatan tersebut hanya berjalan ketika di sekolah tersebut ada acara ataupun ketika siswa mengikuti perlombaan-perlombaan. Ketidakterealisasiannya program-program tersebut dikarenakan kurangnya pengelolaan dari pihak sekolah dalam merealisasikan kegiatan ektrakurikuler sehingga menyebabkan kegiatan ektrakurikuler tidak berjalan dengan lancar. Kegiatan-kegiatan tersebut dilakukan setiap hari Jumat dan Sabtu. Kegiatan ini dibimbing oleh wakasek kesiswaan yang dibantu oleh pembina atau pelatih ektrakurikuler dan dipantau secara langsung oleh kepala sekolah.

Dalam mengembangan bakat dan minat peserta didik perlu adanya pengelolaan ekstrakurikuler yaitu diperlukan seorang pemimipin yang berkompeten, yang mampu mengelola kegiatan ekstrakurikuler yang baik sehingga mencetak generasi yang cerdas dan berkualitas (Yunianto, Suyadi \& Suherman, 2020). Dalam meningkatkan pengelolaan ekstrakurikuler peran 
kepala sekolah sangat besar yang merupakan salah satu sumber dalam meningkatkan mutu pendidikan dan akan membawa pembelajaran yang efektif dan merancang tujuan pendidikan yang unggul dan bermutu (Fitrah, 2017). Kegiatan ekstrakurikuler dikatakan berhasil apabila bisa mengembangkan bakat dan minat yang dimiliki siswa secara baik

Berhasilnya kegiatan ekstrakurikuler ditandai dengan adanya perubahan terhadap pengembangan bakat dan minat yang telah dilakukan peseta didik secara baik (Huda et al., 2019; Rany et al., 2020; Suherman et al., 2020; Yunianto, Negara, \& Suherman, 2019), sehingga dengan sendirinya mampu memperluas wawasan yang akhirnya akan mendukung program intrakurikuler di sekolah. Maka dari itu, sekolah harus menerapkan pelaksanaan kegiatan ekstrakurikuler. Tolak ukur keberhasilan pengelolaan kegiatan di sekolah dapat dilihat dengan adanya suatu perubahan atau efek yang di timbulkan. Apabila tidak dikelola dengan baik, maka akan berpengaruh terhadap peningkatan kualitas peserta didik dan juga sekolah tersebut. Oleh karena itu, pengelolaan kegiatan ekstrakurikuler harus dilakukan secara efektif dan tidak hanya mendukung keberhasilan intrakurikuler, akan tetapi bisa mendukung keberhasilan pendidikan secara luas.

Berdasarkan penjelasan di atas, peneliti tertarik untuk melakukan pengembangan penelitian mengenai kepemimpinan kepala sekolah dalam pengelolaan kegiatan ekstrakurikuler di MI Ma'arif Bego supaya mempunyai daya saing, dan mampu menciptakan generasi yang unggul dalam intelektual, memiliki akhlak sesuai hukum Islam yang dipraktekkan pada kehidupan sehari-hari seperti di sekolah, keluarga, masyarakat serta mampu menghadapi tantangan jaman. Sehingga tujuan penelitian ini adalah untuk mengetahui peran kepemimpinan kepala sekolah dalam pengelolaan ektrakurikuler di MI Ma'arif Bego Yogyakarta.

\section{METODE}

Jenis penelitian yang digunakan menggunakan penelitian kualitatif (Sugiyono, 2008) dengan pendekatan deskriptif kualitatif. Penelitian dilaksanakan di MI Ma'arif Bego. Penelitian ini dilaksanakan pada Mei 2020. Adapun, subjek utama dalam penelitian ini yaitu kepala sekolah di MI Ma'arif Bego dikarenakan kepala sekolah merupakan orang yang mempunyai peranan dan pengaruh dalam menjalankan kegiatan ekstrakurikuler, satu orang wakil kepala sekolah dengan alasan karena wakil kepala sekolah guru yang diberi wewenang untuk mengelola data sisa dan kegiatan yang dilakukan di dalam lingkungan sekolah. Dua guru ekstrakurikuler atau pelatih ekstrakurikuler merupakan pembina yang melaksanakan kegiatan bersama dengan sisiwa serta dapat memberikan informasi bagaimana kegiatan sesungguhnya dilakukan. Tiga orang siswa dan siswa yang mengikuti kegiatan ekstrakurikuler di MI Ma'arif Bego. Siswa-siswi ini dipilih karena memiliki tingkat keaktifan yang tinggi dalam program ekstrakurikuler yang disediakan di MI Ma'arif Bego. Peneliti berpendapat bahwa ketiga siswa tersebut layak digunakan sebagai subjek informasi dari penelitian esktrakurikuler di Mi Ma'arif Bego ini. Adapun, salah satu poin inti dari wawancara yang dilakukan adalah tentang kebijakan dan strategi yang digunakan dalam pengelolaan ektrakurikuler di sekolah tersebut. Informasi ini dapat dijadikan acuan bagi peneliti pada penelitian ini. Subjek penelitian merupakan sesuatu yang bisa memberikan keterangan atau informasi terkait dengan masalah yang kita teliti.

Dalam penelitian ini proses pengumpulan data menggunakan metode wawancara dan dokumentasi. Pada penelitian ini, peneliti mewawancarai kepala sekolah dan pelatih ekstrakurikuler di MI Ma'arif. Sedangkan dokumentasi digunakan untuk memperoleh dokumen-dokumen yang terkait dengan penelitian, baik itu berupa foto-foto maupun data-data lainnya. Analisis data dalam penelitian ini menggunakan analisis Miles dan Huberman yang terdiri dari empat komponen yang saling berkaitan. Komponen tersebut adalah pengumpulan data, reduksi data, penyajian (display) data, verifikasi dan penegasan kesimpulan. Triangulasi data dilakukan dengan menggunakan triangulasi teknik yaitu dengan cara mengecek data dari sumber yang sama, namun dengan teknik yang berbeda. Penelitian ini menggunakan data dari hasil wawancara yang diperoleh, lalu dikonfirmasi atau dicek dengan dokumentasi dan observasi. 
Jurnal Penelitian Ilmu Pendidikan, 14 (1), 2021 - 25

Yunianto, Surohman, \& Hasanah

Hasil

HASIL DAN PEMBAHASAN

Kepala sekolah sebagai pemimpin lembaga pendidikan memiliki posisi yang sangat penting dalam mencapai keberhasilan proses belajar mengajar. Selain itu, kepala sekolah juga berperan penting dalam kegiatan ekstrakurikuler. Sehinga, kepala sekolah dapat memanfaatkan semua potensi yang ada di lembaganya dengan sebaik-baiknya demi mencapai tujuan yang telah direncanakan sebelumnya. Dengan demikian, kepala sekolah sebagai salah satu faktor penting dalam mendorong sumber daya sekolah, seperti sumber daya manusia, sarana prasarana, dan lingkungan sekolah, pencapaian visi, misi, tujuan dan sasaran sekolah dapat dicapai dengan baik. Hasil penelitian ini diperoleh dari wawancara, observasi, dan dokumentasi.

\section{Peran Kepemimpinan Kepala Sekolah dalam Pengelolaan Ekstrakurikuler}

Dalam mengembangkan bakat siswa untuk mencapai prestasi sekolah, pemimpin sekolah harus memiliki strategi dalam meningkatkan bakat siswa. Hal pertama yang harus dilakukan adalah menyadarkan siswa terlebih dahulu terhadap pentingnya pendidikan. Sebagai kepala sekolah maupun guru di sekolah harus mengajari siswa tentang tujuan sekolah itu apa. Supaya mereka bersemangat untuk mencapai tujuan sekolah dan tujuan mereka sendiri di masa mendatang. Apabila siswa-siswi malas dalam hal belajar, kepala sekolah sebagai pemimpin dan guru sebagai pembimbing harus siap memberikan bimbingan, arahan serta bertanggung jawab terhadap mereka tersebut. Dengan demikian, bukan hanya cukup dengan bimbingan saja akan tetapi juga dibantu dengan fasilitas-fasilitas yang memadai di sekolah, misalnya pada sore hari mengadakan kegiatan ekstrakurikuler, seperti pramuka, olahraga dan lainya sehingga dapat meningkatkan bakatnya melalui kegiatan-kegiatan tersebut.

Perencanaan kegiatan ekstrakurikuler ini adalah proses penyusunan dan pembentukan program kerja. Dari uraian kegiatan, target, sasaran, waktu, penanggung jawab hingga sumber dana. Semua itu harus direncanakan dengan baik dan maksimal agar tujuan dari kegiatan ekstrakurikuler tersebut dapat tercapai dengan baik. Mengenai perencanaan ekstrakurikuler ini tentu yang pertama melibatkan kepala sekolah dibantu oleh waka kurikulum dan waka kesiswaan serta guru pembina esktrakurikuler sekolah. Selanjutnya, melakukan koordinasi penyusunan program ekstrakurikuler yang akan dilaksanakan. Kegiatan ekstrakurikuler itu merupakan kegiatan pembelajaran yang dilaksanakan di luar jam pembelajaran sekolah yang biasanya dilaksanakan di sore hari yang bertujuan untuk menambah keterampilan siswa dan menggali potensi yang dimiliki oleh siswa itu sendiri. Kegiatan ekstrakurikuler bisa dikatakan sebagai program yang wajib dilaksanakan di sekolah yang bertujuan untuk menggali potensi bakat dan minat siswa dan itu juga dapat membentuk etika serta akhlaknya sehingga menjadi lebih terampil baik di lingkungan sekolah maupun di masyarakat. Untuk itu kegiatan ini harus dijalankan dengan maksimal supaya dapat menjadi penunjang program intrakurikuler di sekolah.

Berdasarkan hasil wawancara dengan kepala sekolah menunjukkan bahwa pengelolaan ektrakurikuler di MI Maarif Bego sudah baik, kepala sekolah sebagai pemimpin sudah menjalankan tugas dan tanggung jawab dalam mendorong, mempengaruhi, serta melaksanakan hak dan kewajiban lainnya terhadap amanah sebagai pemimpin sekolah. Selain itu, di MI Maarif Bego juga sudah membuat program dan manajemen sekolah serta menjalankannya, baik itu program kerja tahunan, program jangka panjang, pendek dan menengah. Di MI Maarif Bego telah mencoba menerapkan manajemen ekstrakurikuler di sekolah yang dijadikan sebagai acuan kedisiplinan dalam menjalankan setiap kegiatan namun tidak terlaksana secara maksimal. Akan tetapi, kepala sekolah dan pihak sekolah sudah berusaha untuk menerapkan manajemen dengan baik yaitu dengan cara membuat program-program yang akan dilaksanakan baik di bidang akademik maupun di bidang non akademiknya. Sampai saat ini pengelolaan ekstrakurikuler di MI Maarif Bego sudah berjalan dengan baik walaupun memang mengalami sedikit kendala, namun pada umumnya sudah berjalan dengan baik dan lancar.

\section{Kegiatan Ekstrakurikuler}

Ekstrakurikuler dilakukan guna menunjang program pembelajaran, yang dilaksanakan di luar jam pembelajaran biasa. Ekstrakurikuler dilakukan agar dapat meningkatkan potensi yang dimiliki 
siswa yang belum terfasilitasi melalui pembelajaran intrakurikuler. Jenis kegiatan ekstrakurikuler ini bergerak di bidang keagamaan, kesenian, olah raga, dan lain sebaginya. Adapun, kegiatan yang ada di Mi Ma'arif Bego adalah sebagi berikut: a) bidang olah raga, yaitu: sepak bola, badminton, catur, renang dan silat, b) bidang seni, yang terdiri dari kesenian Islami (hadro), c) bidang keagamaan yaitu tahfiz, dan terakhir d) bidang pembinaan program akhlak, sosial, dan kemasyarakatan seperti pramuka. Program-program ini tidak bersifat wajib bagi setiap siswa, namun ada juga yang bersifat wajib. Adapun, program yang bersifat wajib bagi siswa adalah pramuka, yang merupakan tuntutan kurikulum 2013. Program lain yang bersifat wajib juga adalah tahfiz dan silat yang merupakan program unggulan sekoah.

Untuk dapat bergabung dalam berbagai kegiatan ekstrakurikuler di MI Maarif Bego tentunya kepala sekolah atau guru yang menjadi pembina dalam setiap kegiatan tersebut atau wali kelas memberikan arahan mengenai kegiatan ekstrakurikuler yang tidak diwajibkan di sekolah. Pada saat inilah siswa diberi kesempatan untuk menanyakan gambaran dari kegiatan yang akan dilaksanakan. Kemudian, setelah itu membuat pengumuman penerimaan pendaftaran kegiatan ekstrakurikuler. Siswa dapat mendaftar sebagaimana minat dan bakat yang akan mereka kembangkan. Sekolah bertugas untuk memfasilitasi keinginan siswa.

Dari uraian di atas dapat disimpulkan bahwa MI Maarif Bego memiliki beragam jenis kegiatan ekstrakurikuler, ada program wajib seperti pramuka sesuai kurikulum 2013 dan ada yang tidak wajib seperti di bidang olahraga, seni, dan keagamaan.

\section{Kendala yang Dihadapi Kepala Sekolah dalam Pengelolaan Ekstrakurikuler}

Kegiatan yang dilaksanakan tidak akan memiliki perubahan yang signifikan bila tidak dapat mengidentifikasi masalah dan kendala yang ada. Berdasarkan hasil wawancara yang dilakukan dengan kepala sekolah, waka kesiswaan dan pembina ekstrakurikuler, kendala-kendala yang dihadapi kepalas sekolah dalam pengelolaan kegiatan ekstrakurikuler adalah sebagi berikut.

Kendala yang paling menonjol yang dihadapi oleh kepala sekolah di MI Maarif Bego adalah kekurangan guru pembina yang profesional pada masing-masing bidang kegiatan ekskul sehingga membuat kegiatan tidak bisa dilaksanakan sesuai dengan target. Selain itu, juga kurang memadainya fasilitas yang mendukung terlaksananya kegiatan ekskul tersebut, serta masalah pembiayaan yang masih sangat minim sehingga tidak bisa merekrut pembina dari luar karena kekurangan dana.

Hal serupa juga diakui oleh waka kesiswaan, di mana guru pembina di bidang ekstrakurikuler di sekolah masih kurnag. Sekolah masih membutuhkan pembina yang memiliki profesionalitas dalam bidang ekstrakurikuler. Faktor pembiayaan juga menjadi salah satu faktor yang lain. Padahal keberhasilan kegiatan ekstrakurikuler tak lepas dari pemenuhan dan kualitas pembina ekstrakurikuler tersebut. Selain itu, sarana dan prasarana juga menjadi kendala dalam pelaksanaan ekstrakurikuler di mana sarana dan prasarana masih kurang memadai. Sedangkan, kegiatan ekstrakurikuler adalah kebutuhan sekolah untuk membina dan mengembangkan bakat atau keterampilan siswa dalam menunjang program pembelajaran biasa di sekolah. Selain itu juga, terdapat kendala yang berasal dari siswa, mengenai jarak sekolah dengan tempat tinggal siswa yang lumayan jauh dengan sekolah sehingga tidak bisa mengikuti kegiatan ekstrakurikuler. Sedangkan, pelaksanaan ekstrakurikuler yang tidak wajib dilakukan di sore hari setelah pembelajaran selesai atau pulang sekolah. Itu juga merupakan kendala yang dihadapi sekolah dalam pengelolaan ekstrakurikuler.

Di setiap oraganisasi apapun baik pendidikan ataupun non pendidikan memiliki beberapa masalah dalam penyelenggaraan kegatannya, begitu juga di lembaga pendidikan MI Ma'arif Bego yang juga memiliki kendala. Dari hasil wawancara yang telah dilakukan, dapat disimpulkan bahwa MI Ma'arif Bego dalam pelaksanaan kegiatan ekstrakurikuler mengalami beberapa kendala yaitu kendala pembiayaan, kurangnya pembina, dan belum memadainya sarana dan prasarana sebagai penunjang proses kegiatan ekstrakurikuler. Kendala-kendala tersebut juga dapat menumbuhkan solusi yang dapat digunakan untuk mengatasi masalah tersebut. Solusi untuk mengatasi beberapa masalah yang ada di MI Ma'arig Bego yang didapatkan dari hasil wawancara dengan kepala sekolah selaku pimpinan tertinggi antara lain: a) kendala kurangnya guru pembimbing yaitu dengan bekerja sama dengan alumni MI Ma'arif Bego yang mempunyi keahlian di bidang ekstrakurikuler yang dibutuhkan dan bersedia untuk dijadikan pelatih atau pembimbing kegiatan ekstrakurikuler tersebut. Selain itu, juga dibantu oleh guru-guru yang memiliki kualifikasi yang serupa; b) kendala dalam pembiayaan 
yaitu dengan kerja sama pihak sekolah, komite, dan orang tua wali murid guna mencari kesepakatan yang dapat disetujui oleh kedua belah pihak. Di mana pihak sekolah menyampaikan pentingnya kegiatan ekstrakurikuler dan kendala pembiayaan terhadap komite sekolah dan wali murid, kemudian komite dan orang wali murid dapat mengambil tindakan guna membantu dari segi finansial untuk kelancaran proses kegiatan di sekolah; c) kendala dalam bidang sarana dan prasarana untuk sementara waktu dengan menggunakan atau memanfaatkan fasilitas sekolah yang ada.

Selain itu, waka kesiswaan juga menjelaskan bahwa untuk mengatasi solusi yang muncul yang berkaitan dengan kegiatan ekstrakurikuler yaitu: pihak sekolah melaksanakan kerja sama dengan komite sekolah dan wali murid guna mendiskusikan permasalahan yang dihadapi oleh sekolah. Kemudian, dari musyawarah tersebut dapat memunculkan solusi bersama seperti persoalan kurangnya dana pengelolaan ekstrakurikuler yang diambil sebagian dari dana sekolah serta dibantu oleh komite dan sumbangan dari orang tua siswa. Selanjutnya, persoalan kurangnya pembina ekstrakurikuler yaitu dengan memberikan motivasi dan dukungan kepada siswa, sehingga siswa memahami bahwa keterbatasan bukan berarti tidak berkarya sama sekali, serta dapat tetap kreatif, inofatif, dan berfikir positif. Langkah lain yang dilakukan waka kesiswaan adalah meningkatkan kesadaran dan kedisiplinan siswa dengan cara membentuk kerja sama dengan orang tua siswa. Kerja sama tersebut guna menumbuhkan dukungan penuh dari orang tua terhadap anaknya agar anak-anak tersebut dapat memiliki semangat yang tinggi dan memiliki rasa tanggung jawab dan keingingan tinggi terhadap masa depan yang cemerlang.

Dari uraian di atas dapat disimpulkan bahwa dalam menangani masalah dan persoalan yang muncul di MI Ma'arif Bego mengenai masalah kurangnya guru pembina dapat dilakukan dengan cara bekerjasama dengan alumni sekolah sebagai pelatih ekstrakurikuler. Adapun, untuk masalah yang berkaitan dengan pembiayaan dan sarana yang belum memadai dengan membuat kerjasama antara pihak sekolah dengan komite sekolah serta wali murid yang dapat memberikan bantuan kepada pihak sekolah.

\section{Pembahasan}

\section{Peran Kepemimpinan Kepala Sekolah dalam Pengelolaan Ekstrakurikuler}

Hasil penelitian ini menunjukkan bahwa kepala sekolah sebagai pimpinan tertinggi yang ada di sekolah dalam menjalankan kepemimpinannya sudah baik. Kepala sekolah memiliki kompetensi yang baik dan memiliki tanggung jawab yang tinggi terhadap tugas-tugas sebagai kepala lembaga. Hal ini seperti yang dijelaskan oleh Hartinah (Hartinah et al., 2019) bahwa kepemimpinan merupakan kemampuan untuk menggerakkan, mempengaruhi, memotivasi, mengajak, mengarahkan, menasihati, membimbing, menyuruh, memerintah, melarang, dan bahkan menghukum (bila diperlukan) serta membina dengan maksud agar manusia sebagai media mengatur dan dapat bekerja dengan baik dalam rangka mencapai tujuan administrasi secara efektif dan efisien.

Kepala sekolah yang memiliki peranan penting dalam menggerakkan bawahannya dan memiliki tanggung jawab penuh terhadap semua kegiatan yang ada di sekolah. Seorang pemimpin harus mampu memberikan bimbingan, instruksi, arahan, dan membentuk team work yang baik untuk memperoleh tujuan yang diinginkan. Kepala sekolah harus memiliki karakteristik yang rendah hati, memberi keteladanan, tegas, optimis, bijaksana, dan bersahabat (Ashdown \& Bernard, 2012).

Strategi kedua yang dilakukan oleh kepala sekolah terhadap pengelolaan ekstrakurikuler di MI Ma'arif Bego yaitu dengan melakukan supervisi secara rutin yang dilakukan satu bulan sekali. Supervisi ini dilakukan dengan meninjau atau mengawal sejauh mana proses kegiatan ekstrakurikuler berlangsung. Pengawasan ini menyoroti tentang penggunaan metode, materi, dan kehadiran pembina. Segala usaha pejabat sekolah dalam memimpin guru-guru dan tenaga kependidikan lainnya, untuk memperbaiki sistem pengajaran serta menstimulasi, menyeleksi pertumbuhan dan perkembangan jabatan guru-gruru, menyeleksi, dan memperbaiki tujuan-tujuan pembelajaran, bahan ajar, metode mengajar dan melakukan evaluasi pengajaran. Selain itu, juga fungsi supervisi yaitu untuk memberi petunjuk, mendorong, menjelaskan, membimbing, dan mampu meningkatkan situasi belajar, serta membantu para guru agar ia mengajar lebih baik (Elliott, Isaacs \& Chugani, 2010).

Berdasarkan uraian di atas, dapat disimpulkan bahwa peran kepala sekolah di MI Ma'arif Bego dalam menjalankan kegiatan ekstrakurikuler sudah baik. Kepala sekolah sudah sangat aktif dan 
kreatif dalam mengembangkan sekolah yang lebih efektif. Peran kepala sekolah yang terpenting adalah sebagai pemimpin yang harus memiliki kepribadian baik dan mampu bekerja sama dengan seluruh civitas academica sekolah dalam menyusun perencanaan program sekolah serta pengawasannya. Peran kepala sekolah ini sangat penting karena dapat meningkatkan komitmen guru di sekolah, seperti gaya kepemimpinan transformasional (Ibrahim et al., 2014). Dengan meningkatnya komitmen guru, sikap kepemimpinan kepala sekolah dapat diturunkan kepada siswa sehingga siswa dapat memiliki komitmen terhadap ekstrakurikuler yang dipilihnya. Soft skill yang ditunjukkan guru tersebut dapat membantu siswa di masa yang akan datang (Don, Raman, Hussin \& Kasim, 2016).

\section{Kegiatan Ekstrakurikuler}

Kegiatan ekstrakurikuler merupakan kegiatan yang bersifat nonformal yang dilakukan di luar kegiatan formal, sebagai upaya untuk menambah pengetahuan dan memperdalam materi-materi secara lebih konkret yang diajarkan di sekolah dengan bantuan guru atau pengampu ekstrakurikuler agar dapat digunakan dalam kehidupan nyata. MI Maarif Bego memiliki berbagai macam kegiatan ekstrakurikuler baik di bidang olahraga, seni, keagamaan, dan pramuka. Seperti yang diungkapkan oleh Pembinaan di MI Maarif Bego jenis kegiatan ekstrakurikuler adalah sebagai berikut: a) Bidang olahraga yaitu: sepakbola, badminton, catur, renang, dan silat; c) Bidang seni, yaitu: hadro; d) Bidang keagamaan yaitu: tahfiz, dan e) Dengan dilaksanakannya ekstrakurikuler ini siswa dapat menyalurkan kegiatan yang berkaitan dengan bakat dan minatnya yang ada dalam kegiatan kepramukaan dan dapat membantu siswa memahami kepemimpinan di antara temannya serta kedisiplinan. Hal ini sesuai dengan manfaat kegiatan ekstrakurikuler yang diungkapkan oleh Mette (Mette et al., 2015) bahwa: a) meningkatkan kemampuan siswa dalam menjalin hubungan yang saling timbal balik terhadap lingkungan sosial, budaya, dan alam semesta sebagai bagian dari anggota masyarakat secara umum; b) menyalurkan dan mengembangkan potensi dan bakal siswa agar menjadi masusia yang memiliki kreativitas tinggi dan penuh karya; c) melatih sikap disiplin waktu, tanggung jawab, sikap jujur, dan kepercayaan dalam menjalankan tugas; d) mengembangkan siswa yang beretika dan berakhlak dengan meningkatkan hubungannya dengan Tuhan, Rasul, manusia, diri sendiri bahkan alam semesta; e) mengembangkan sensitivitas sosial keagamaan siswa dalam kehidupan sehari-hari sehingga menjadi manusia yang produktif terhadap masalah sosial keagamaan; f) memberikan bimbingan, pelatihan dan arahan kepada siswa agar memiliki fisik yang sehat, bugar, cekatan, kuat, dan trampil; g) memberikan kesempatan kepada siswa agar mampu berkomunikasi dengan baik secara verbal atau nonverbal terhadap teman sendiri ataupun masyarakat setempat. Hal ini sejalan dengan pendapat Pulungan (Akpan \& Beard, 2016), bahwa ektrakurikuler bertujuan untuk menyediakan lingkungan yang memungkinkan siswa untuk mengembangkan potensi, bakat, dan kemampuanya secara optimal, sehingga mereka mampu mewujudkan dirinya dan berfungsi sepenuhnya sesuai dengan kebutuhan pribadinya maupun masyarakat.

Dari uraian di atas dapat disimpulkan bahwa MI Maarif Bego telah memberikan pelayanan yang baik bagi siswa dalam hal akademik atau intrakurikuler ataupun nonakademik atau ekstrakurikuler. Jenis kegaitan ekstrakurikuler yang ada di MI Ma'arif Bego telah sesuai dengan visi dan misi sekolah. Setiap kegiatan ekstrakurikuler ini dapat membantu siswa mengenali dan menggali potensi dirinya serta dapat membentuk karakter pribadi yang baik. Kegiatan ekstrakurikuler juga dapat meningkatkan nilai akademik siswa secara bertahap, hal ini terjadi karena perasaan baik dan percaya diri setelah mengikuti kegiatan tersebut. Kegiatan ekstrakurikuler juga melatih kegiatan sosial anak secara lebih baik (Balyer \& Gunduz, 2012). Selain itu, juga kegiatan ektrakurikuler mampu menumbuhkan kepercayaan diri, kedisiplinan, keberanian siswa berbicara di depan umum (Butt, 2016), menumbuhkan kemandirian dan kedewasaan yang dapat mengubah cara berpikir anak dalam menghadapi permasalahan dalam hidupnya. Keberhasilan ekstrakurikuler ini tidak hanya dengan layanan yang disediakan oleh lembaga pendidikan, peran orang tua dan kelas sosial juga mempengaruhi hasil ekstrakurikuler anak. Orang tua yang dulunya pernah mengikuti ekstrakurikuler, anaknya cenderung mengikuti ekstrakurikuler yang sama juga (Ashbourne \& Andres, 2015).

\section{Kendala yang Dihadapi Kepala Sekolah dalam Pengelolaan Ekstraukrikuler}

Dari paparan di atas, dapat disimpulkan bahwa kendala yang dialami kepala sekolah MI Ma'arif Bego dalam pengelolaan ekstrakurikuler adalah kurangnya pembiayaan serta minimnya guru 
pembina ekstrakurikuler. Untuk mengatasi msalah ini diperlukan kebijakan kepala sekolah dan pengambilan keputusan yang tepat guna menghadapi kendala-kendala tersebut yaitu dengan memberdayakan guru yang mampu membantu dalam ekstrakurikuler yang ada, melakukan kerja sama dengan komite dan memberi motivasi kepada anak-anak dengan perantara guru pembina. Tugas-tugas kepemimpinan harus dimiliki kepala sekolah dengan baik, yakni kepala sekolah mampu mengelola kurikulum, administrasi guru, administrasi personalia, administrasi sarana dan prasarana, administrasi kearsipan dan keuangan. Kegiatan tersebut harus dilakukan secara efektif dan efisien agar produktivitas sekolah dapat tercapai dengan baik.

Dari uraian di atas dapat disimpulkan bahwa kemampuan kepala sekolah terhadap manajemen sekolah memiliki faktor krusial dalam melaksanakan program-program sekolah. Karena pemimpin merupakan promotor penggerak suatu lembaga yang dipimpinnya. Untuk menghasilkan siswa dengan hasil ekstrakurikuler yang baik, kepala sekolah dapat memobilisasi civitas academica guna mendukung keberhasilan ekstrakurikuler tersebut.

\section{PENUTUP}

Kepala sekolah dalam menjalankan kepemimpinan mengenai kegiatan ekstrakurikuler sudah baik. Kepala sekolah memiliki kompetensi yang baik dalam melakukan tugas-tugasnya. Kegiatan ekstrakurikuler yang ada di MI Maarif Bego yaitu silat, tahfiz, pramuka, sepakbola, badminton, catur, renang dan hadro. Adapun, ekstrakurikuler yang diwajibkan kepada siswa adalah pramuka, silat dan tahfiz. Sedangkan, kendala-kendala yang dialami di MI Maarif Bego antara lain adalah: ketersediaan guru, fasilitas, dan kendala musim. Kendala guru biasanya guru memiliki kepentingan yang lain dalam menghambat kemajuan kegiatan ekstrakurikuler di sekolah.

\section{UCAPAN TERIMA KASIH}

Peneliti menyampaikan terima kasih kepada kepala sekolah, dan guru-guru di MI Maarif Bego serta terima kasih kepada Dr. Istiningsih, M.Pd yang memberikan masukan dan arahan dalam penulisan artikel ini.

\section{DAFTAR PUSTAKA}

Akpan, J. P., \& Beard, L. A. (2016). Using constructivist teaching strategies to enhance academic outcomes of students with special needs. Universal Journal Of Educational Research, 4(2), 392-398.

Andriani, S., Suyitno, H., Junaidi, I., Suherman, S., Mujib, M., \& Mardiyah, M. (2019). The application of differential equation of verhulst population model on estimation of bandar lampung population. Journal Of Physics: Conference Series, 1155, 012017.

Ashbourne, D., \& Andres, L. (2015). Athletics, music, languages, and leadership: how parents influence the extracurricular activities of their children. Canadian Journal Of Education, $38(2), \mathrm{N} 2$.

Ashdown, D. M., \& Bernard, M. E. (2012). Can explicit instruction in social and emotional learning skills benefit the social-emotional development, well-being, and academic achievement of young children? Early Childhood Education Journal, 39(6), 397-405.

Balyer, A., \& Gunduz, Y. (2012). Effects of structured extracurricular facilities on students' academic and social development. Procedia-Social And Behavioral Sciences, 46, 4803-4807.

Butt, R. (2016). Teacher assistant support and deployment in mainstream schools. International Journal Of Inclusive Education, 20(9), 995-1007.

Don, Y., Raman, A., Hussin, F., \& Kasim, K. (2016). The role of teacher leadership and extracurricular activities in the construction of the soft skills of secondary school students in malaysia. International Journal Of Academic Research And Development, 1(3), 89-95.

Elliott, E. M., Isaacs, M. L., \& Chugani, C. D. (2010). Promoting self-efficacy in early career teachers: A principal's guide for differentiated mentoring and supervision. Florida Journal of Educational Administration \& Policy, 4(1), 131-146. 
Fitrah, M. (2017). Peran kepala sekolah dalam meningkatkan mutu pendidikan. Jurnal Penjaminan Mutu, 3(1), 31-42.

Hartinah, S., Suherman, S., Syazali, M., Efendi, H., Junaidi, R., Jermsittiparsert, K., \& Umam, R. (2019). Probing-prompting based on ethnomathematics learning model: The effect on mathematical communication skill. Journal For The Education Of Gifted Young Scientists, 7(4), 799-814.

Huda, S., Komarudin, K., Suherman, S., Syazali, M., \& Umam, R. (2020). The effectiveness of alqurun teaching model $(\mathrm{atm})$ viewed from gender differences: The impact on mathematical problem-solving ability. Journal Of Physics: Conference Series, 1467, 012001.

Huda, S., Rinaldi, A., Suherman, S., Sugiharta, I., Astuti, D. W., Fatimah, O., \& Prasetiyo, A. E. (2019). Understanding of mathematical concepts in the linear equation with two variables: impact of e-learning and blended learning using google classroom. Al-Jabar: Jurnal Pendidikan Matematika, 10(2), 261-270.

Ibrahim, M. S., Ghavifekr, S., Ling, S., Siraj, S., \& Azeez, M. I. K. (2014). Can transformational leadership influence on teachers' commitment towards organization, teaching profession, and students learning? a quantitative analysis. Asia Pacific Education Review, 15(2), 177-190.

Kasidah, M. A. (2017). Kepemimpinan kepala sekolah dalam meningkatkan kinerja guru pada sekolah dasar luar biasa negeri Banda Aceh. Jurnal Administrasi Pendidikan: Program Pascasarjana Unsyiah, 5(2).

Kodiran, K. (2017). Kepala sekolah sebagai tugas tambahan. Al-Idarah: Jurnal Kependidikan Islam, $7(1), 146-158$.

Makmur, J. (2012). Tips menjadi kepala sekolah yang profesional. Jogjakarta: Diva Press.

Mette, I. M., Range, B. G., Anderson, J., Hvidston, D. J., \& Nieuwenhuizen, L. (2015). Teachers' perceptions of teacher supervision and evaluation: a reflection of school improvement practices in the age of reform. Education Leadership Review, 16(1), 16-30.

Rany, W., Suherman, S., Anggoro, B. S., Negara, H. S., Yuliani, M. D., \& Utami, T. N. (2020). Understanding mathematical concept: The effect of savi learning model with probingprompting techniques viewed from self-concept. Journal Of Physics: Conference Series, 1467, 012060.

Sugiyono. (2008). Metode penelitian pendidikan: Pendekatan kuantitatif, kualitatif dan $r \& d$. Bandung: Alfabeta.

Suherman, S., Prananda, M. R., Proboningrum, D. I., Pratama, E. R., Laksono, P., \& Amiruddin, A. (2020). Improving higher order thinking skills (hots) with project based learning (pjbl) model assisted by geogebra. Journal Of Physics: Conference Series, 1467, 012027.

Umar, H. (2001). Proses belajar mengajar. Jakarta: Bumi Aksara.

Yunianto, T., Negara, H. S., \& Suherman, S. (2019). Flip builder: Pengembangannya pada media pembelajaran matematika. Terampil: Jurnal Pendidikan Dan Pembelajaran Dasar, 6(2), $115-127$.

Yunianto, T., Suyadi, S., \& Suherman, S. (2020). Pembelajaran abad 21: Pengaruhnya terhadap pembentukan karakter akhlak melalui pembelajaran stad dan pbl dalam kurikulum 2013. Premiere Educandum: Jurnal Pendidikan Dasar Dan Pembelajaran, 10(2), 203-214. 